\title{
POTENTIAL OF HILL COUNTRY FARMING IN THE KING COUNTRY
}

\author{
P. G. YeOMAN
}

Farm Advisory Officer, Ministry of Agriculture and Fisheries, Te Kuiti

A bstract

The evidence available on pasture production in the King Country is reviewed and compared with stock requirements. A potential carrying capacity of 19 stock units/ha in the Waitomo County is estimated. It is shown that, when product prices are high,. the economic optimum stocking rate is near the point 'beyond which stock will be seriously underfed. Management techniques aimed at producing and utilizing pasture feed efficiently and also allowing flexibility in stocking rates to meet varying economic conditions are outlined.

\section{INTRODUCTION}

The AIm of this Paper is to discuss the potential of King Country hill country. This involves suggesting what levels of production are possible in the future. However, there seems to be little point in doing this unless both the desirability and some practicable means of approaching this potential can also be established.

A paper presented at this conference has described the present farming patterns in the King Country and from this description of the area it can be seen that there is potentiall to increase hill country production in two distinct ways. The grazable area can be increased by developing more land, or production from the existing grazable area can be increased. This paper deals specifically with the problem of increasing production from the developed land, which it has been estimated carries about 11 stock units/ha at present.

\section{PASTURE PRODUCTION}

Ruakura data on the feed requirements of sheep (Joyce and Maclean, 1970) suggest that at present on average about $6000 \mathrm{~kg}$ $\mathrm{DM} /$ ha are being utilized. To gain an idea of the hill country potential, it is necessary to determine how much dry matter is, or can be, produced in this area. 
Attempts have been made to measure hill country pasture pro duction locally, but the results are few and, because of the inherent variability of hill country, are themselves varied. There is also the problem of technique. There is still no technique available which will satisfactorily measure pasture available to stock. Measurements made have given annual pasture production ranging from about $4000 \mathrm{~kg} \mathrm{DM} /$ ha on southerly mudstone soils to over $12000 \mathrm{~kg} \mathrm{DM} / \mathrm{ha}$ on Mairoa ash ridge tops.

Another means of estimating pasture production is to calculate the feed utilized by stock under intensive grazing conditions. On this basis, cattle on the beef demonstration unit on N.Z. Pastoral Holdings property utilized about $12500 \mathrm{~kg} \mathrm{DM} / \mathrm{ha}$ in one year (Smith, unpublished data). Under similar grazing conditions, a local farmer's cattle utilized an estimated $12000 \mathrm{~kg}$ $\mathrm{DM}$ /ha in 1972-3.

On the evidence available, a conservative estimate is that the Mairoa ash country is capable of averaging $11000 \mathrm{~kg} \mathrm{DM} /$ ha annually and the other soil types at least $7000 \mathrm{~kg} \mathrm{DM} / \mathrm{ha}$.

\section{POTENTIAL STOCK PRODUCTION}

It is now possible to get an idea of the potential stock carrying capacity of this district. If the estimated pasture production potential of the different soil types is expressed in terms of feed requirements for stock and it is assumed that at least half of the grazable area in the county is Mairoa ash, the potential carrying capacities shown in Table 1 are obtained.

TABLE 1: ESTIMATED POTENTIAL CARRYING CAPACITIES ON WAITOMO HILL COUNTRY

\begin{tabular}{|c|c|c|c|c|c|c|}
\hline & & & 54 & $\mathrm{~kg}$ Ewe & 45 & $\mathrm{~kg}$ Ewe \\
\hline Ash soils & $\ldots$ & $\ldots$ & $\ldots$ & 19 & & 22 \\
\hline Other soils & $\ldots$ & $\ldots$ & $\ldots$ & 12 & & 14 \\
\hline Weighted county & average & $\ldots$ & & 17 & & 19 \\
\hline
\end{tabular}

This table is based on ewes of two different liveweights. If the lower animal performance implied by the lower of the two ewe liveweights is accepted as a basis, then it should be possible to lift the present average carrying capacity from 11 to about 19 stock units/ha. 


\section{ECONOMIC ASPECTS}

Having considered what is possible, the next question to answer is whether it is also desirable. It must be remembered that farmers do not aim at maximum production but rather their aim is to maximize profitability, which can be a quite different thing.

As stocking rates increase under any given management system, the feed available to each individual animal decreases and there is a tendency for production per animal to fall. The overall effect on profitability depends on the extent to which the fall in per-animal production land the added cost of running extra stock nullify the added production of the extra stock farmed.

The effects on production of changing the stocking rate were studied in a trial carried out at Ruakura (Joyce, 1971) which compared the performance of five- and six-year-old ewes grazed at 20, 25 and 30 ewes/ha, on a pasture reportedly producing $14570 \mathrm{~kg} \mathrm{DM} / \mathrm{ha}$. At the highest stocking rate, the ewes were not completely self-contained for feed and consequently this stocking rate indicates the point at which animal performance would drop rapidly.

Figure 1 shows the 'marginal profits achieved by increasing the stocking rate from $20 /$ ha in this trial. In other words, the points on the graph represent the increased net profits obtained from increasing the stocking rate.

From Fig. 1 it can be seen that, when prices are low relative to variable costs, as was the case in 1971-2, maximum profit is obtained at a lower stocking rate than is the case under the high prices of 1972-3. Under the conditions of this trial, the most profitable stocking rate with $1972-3$ prices lies close to the maximum rate studied.

These results can be related to the King Country situation by using the dry matter actually available per hectare for each ewe run at the different stocking rates. On this basis the highest trial stocking rate is equivalent to about 22 ewes/ha on the ash country at its suggested potential pasture production.

This result means that while prices are high the potential stocking rates 'suggested earlier are likely to be profitable.

\section{NECESSARY MANAGEMENT}

This leads to a consideration of some of the management systems needed to farm at high stocking rates. To do this success- 


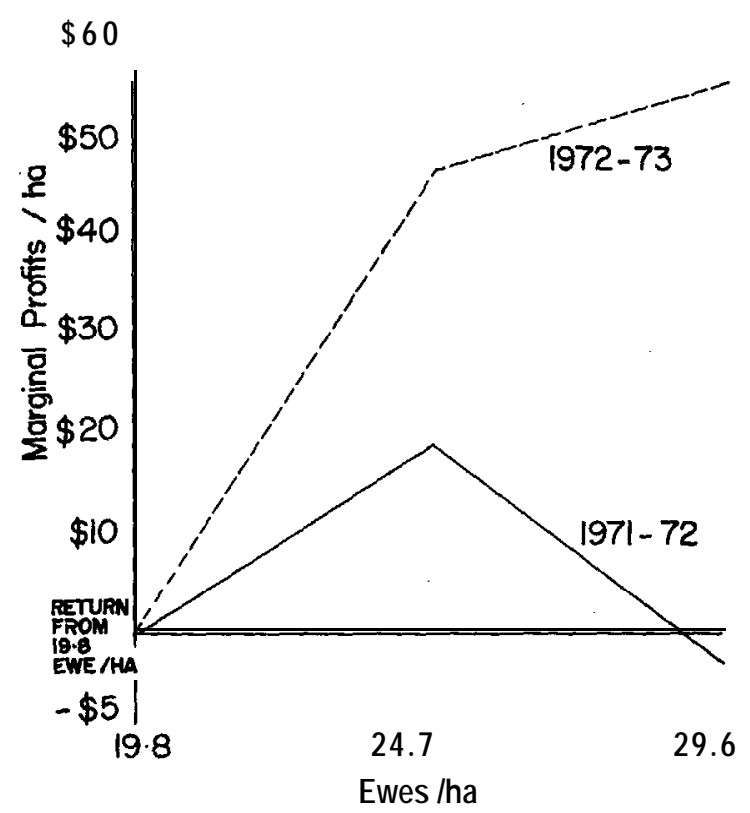

FIg. 1: Marginal profits achieved at different stocking rates under 1971-2 and 1972-3 prices.

fully and to achieve consistent high profitability require considerable management changes in four basic 'areas:

(1) Increasing total dry matter production and improving the annual spread of production.

(2) Achieving more efficient utilization of the feed produced.

(3) Improving the efficiency of the stock that are run.

(4) Permitting farming systems to be more flexible.

\section{Increasting Dry Matter Production and Spread}

Quite obviously if the potential carrying capacity of the hill country is to be approached, the dry matter production must be raised to its potential. It is also necessary, however, to improve the annual spread of pasture growth.

Figure 2 shows the 'average daily dry matter production measured on one paddock at the Te Kuiti Field Research Area in 197 1-2 (J. A. Baars, unpublished data). The measurements 


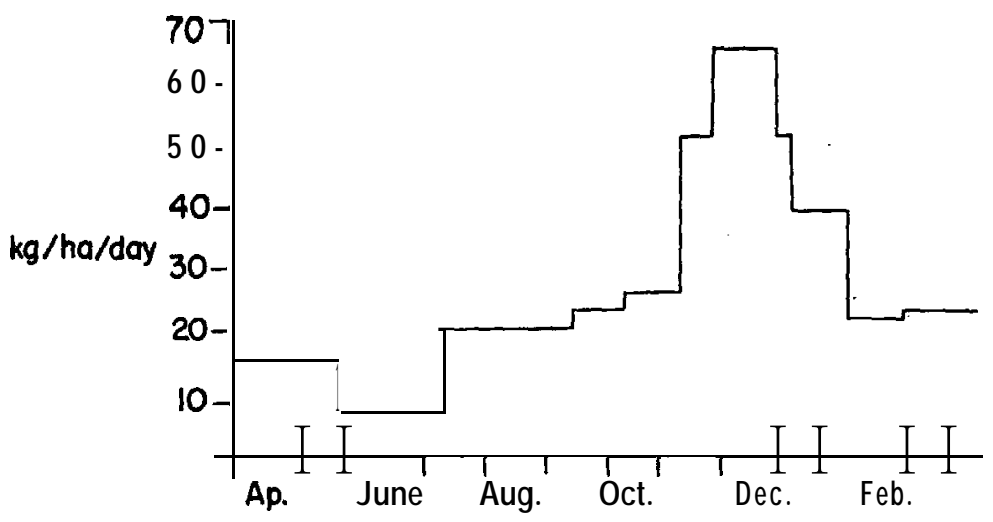

FIG. 2: Average daily dry matter production from one paddock at the Te Kuiti Field Research Area, 1971-2.

were made on a paddock set-stocked with sheep for most of the year and the "difference" technique described by Radcliffe (1971) was used.

The graph indicates the marked peak of pasture production over the November-December period. This pattern of pasture growth is difficult to match with stock requirements. Pastures tend to get away from stock in the spring and summer and growth over the winter can be too low to support the stock that can be grazed at other times of the year.

The two most potent itools to affect both the total dry matter production and the seasonal spread of growth are fertilizer and subdivision.

Two of the other papers presented at this conference describe the fertilizer responses of, soils in this area. Research has shown that local Mairoa ash soils will respond to up to $1000 \mathrm{~kg} / \mathrm{ha}$ of superphosphate and that the hill soils derived from sedimentary rocks will respond to up to $500 \mathrm{~kg} / \mathrm{ha}$. Provided the stocking rate is high enough for the extra feed stimulated to be fully utilized, these topdressing rates are likely to be profitable when product prices are high.

A further benefit of increased topdressing, when coupled with sound rotational grazing, is to improve the annual spread of pasture production by allowing improved pasture species to 
develop. The increase of the ryegrass and clover contents in the sward, and the improvement of autumn, winter and spring growth have been found by many local farmers to follow increased topdressing of their farms.

One of the present problems of hill country farming is the lack of subdivision. It is common to find only three or four paddocks available to each class of stock on a farm. This contrasts with the twelve to fifteen paddocks used with the intensive rotational grazing systems utilizing $12000 \mathrm{~kg} \mathrm{DM} /$ ha quoted earlier.

To achieve high pasture production, more paddocks in relation to the number of mobs of stock are essential. This will probably require both an increase in subdivision and a reduction in the number of mobs of stock carried, possibly by grouping a number of classes together according to their feed demands at any one time.

Hand in hand with these developments must go management. In this connection, one cannot over-emphasize the need for a thorough clean-up of pastures in the autumn to bring about the switch from summer growing to winter growing dominance.

\section{Improved Pasture Utilization}

The achievement of this aim is closely related to that of increased pasture production. With high stocking rates run rotationally under close subdivision, utilization, in terms of the proportion of feed grown that is eaten, will be improved.

It is also necessary to consider the efficiency of use of the feed eaten. At high stocking rates, stock will be fed at less than appetite and concern is therefore with rationing the feed avail\&e, to ensure that the right amount goes to the right animals at the right time. This requires an appreciation of the feed requirements of different classes of stock at different times of the year and the allocation of available feed between classes on this basis.

The concept of feed budgeting could be very useful for hill country farmers as an aid to rationing and this topic is discussed in a number of papers presented to this conference. Temporary electric fencing to break-graze in the winter and spring, and tupping harnesses and pregnancy diagnosis to identify pregnant animals will also help in allocating and rationing pastures. 
3. IMPROVING THE EFFICIENCY OF STOCK

Improvement of stock performance can take place at the same time as stocking rates are being raised. There are two controllable factors affecting stock performance - feeding and breeding. Feeding has already been referred to in terms of rationing feed to stock to ensure that they are adequately fed at the most important periods.

There is still considerable scope for breeding more efficient stock. This depends largely on identifying 'animals superior in economically important characters and selecting from them. In this regard the recently initiated beef recording "scheme "Beefplan" will be very significant.

A major improvement in efficiency could be achieved by bringing forward first mating of sheep and cattle. If sheep are mated as hoggets and cattle as 15-month-old heifers, it is possible to fit effectively an extra lambing or calving into a lifetime and so reduce the "overheads" in cost and feed per lamb or calf born.

This can be done successfully in this area as some farmers have shown, but it requires good feeding of young stock to ensure that there are no harmful effects in later life. Hoggets need to be about $35 \mathrm{~kg}$ liveweight by April and heifers 250 to $270 \mathrm{~kg}$ liveweight at 15 months of age. Pregnant young stock also need to be adequately fed after mating land very well fed during lactation.

These requirements mean that the potential gain in efficiency that could come from early mating will be realized only after the treatment of young stock on the hill country has been improved. Heifers and hoggets must be looked on as two of the most profitable classes of stock run. The impact of early feeding on lifetime performance is too great to be ignored.

\section{Achieving Flexibility}

A farming system based on high stocking rates and aimed at consistent high profitability must have a considerable degree of flexibility built into it. An obvious need 'arises from the variation between years and within years in pasture production. To counter this, a highly stocked farmer needs to be able to alter his stocking rate to suit the season, possibly by buying and selling some class of stock.

The other prime need for flexibility arises from the shift in optimum economic stocking rate as prices change, illustrated 
earlier. To cope with changes in prices, a farmer needs to be able to increase or decrease his stock numbers rapidly and he also needs to be able to shift rapidly from one class of stock to another. Recent history shows this very clearly.

The rate at which /breeding 'stock numbers can be increased depends on fertility, the culling rate that is needed to maintain a satisfactory flock or herd, and the time stock must be carried before they can be used for breeding. This emphasizes the need to improve the. breeding land feeding of stock and also the desirability of mating female stock as hoggets and 15-month-old heifers.

\section{CONCLUSION}

Estimates of potential pasture production and the feed requirements of stock indicate that it should be possible to increase the number of stock carried on the hill country at present in grass by at least $\mathbf{7 0} \%$.

The decision to raise production towards this potential lies with the individual farmers of the district and can only be taken after looking at the changes in management and the increases in costs that must be set against the increased returns on each individual farm. From this paper, however, it can be concluded that, provided the necessary changes in management and farm practice are carried out, then, under the comparatively high prices prevailing in the 1972-3 year, high stocking rates approaohing the potential of the land 'are likely to be profitable for many farmers.

\section{ACKNOWLEDGEMENTS}

I should like to acknowledge the contributions of various farmers and colleagues who have helped with the evolution of the ideas presented. I am grateful to Dr J. A. Baars and H. Foskett of the Field Research Section, Ministry of Agriculture and Fisheries, for data supplied by them.

\section{REFERENCES}

Joyce, J. P., 1971: Proc. R uakura Fmrs' Cont.; 13-24.

Joyce, J. P.; Maclean, K. S., 1970: Proc. Ruakura Fmrs" Conf.: 15-25. Radcliffe, J. E., 1971: Proc. N.Z. Grassld Ass., 33: 91-104. 